\title{
Environmental solution for traditional housing in the Cuu Long River delta
}

\author{
Anh Dung Pham ${ }^{1, *}$ \\ ${ }^{1}$ Department of Urban Engineering, University of Architecture Ho Chi Minh City, 196 Pasteur street, \\ ward 6, District 3, Ho Chi Minh City, Vietnam
}

\begin{abstract}
Experience of environmental solutions for traditional housing in a certain region is always considered as a base in local housing construction. Due to common scientific methods of site survey - statistics - deduction historic documentation, the researcher expects to propose lessons learnt from ancestor's logical behaviors on environmental solutions for traditional housing in the Cuu Long River Delta in order to propose fundamental solutions for current local housing construction.
\end{abstract}

\section{Introduction}

\subsection{Research necessity}

Environmental issues is always taken into consideration everywhere at any time for every people. In the Cuu Long River Delta - Vietnam (called the Southern Vietnam) about from 300 years ago to the middle of the century, when poor Vietnamese migrants as newcomers came to reside this land. The living environment here is severely harsh at that time. As stated by researcher Nguyễn Đình Đầu, "is the land of wild, forest, pond, desolated, full of mosquitoes, centipede and snake; ferocious tiger and panther"; ... hot and wet weathers, with 2 seasons (dry and rainy seasons); That is the reason why the people in the Cuu Long River Delta from long time ago, with their own living experiences, have efficiently adapted their life to that harsh weather condition. One of those serious preparations, which directly affected to their livings, is to create their house to adapt to local weather environment. This housing construction adapted to environment respects both environmental issues and unique traditional culture.

Nowadays the Cuu Long River Delta conditions is less severe, but values from lesson learnt from these days have been kept unchanged in terms of environmental issues, due to the fact of global weather change concern. The new consideration raises - a new behavior new approach for future housing environment in the Cuu Long River Delta comes into play, in which traditional lessons play an important role in the new contemporary and future housing approach in the region. To this concern: Environmental solutions in traditional housing construction in the Cuu Long River Delta. This has been largely researched in previous time; but these were generally done only. For instance, as stated in the book:

${ }^{*}$ Corresponding author: kts.anhdung@yahoo.com 
"Vietnamese traditional houses in Vinh Long", as written by the author: "in such a natural condition, people in Vinh Long province has gradually adapted to their living condition, in which housing is considered as a lively evidence" [5]. Or, in another book "Old housing architecture in Dong Nai province", as generally described by the author: "Ancient houses in Dong Nai appeared at the beginnings from last $19^{\text {th }}$ to late $20^{\text {th }}$ century. They were called ancient house as they were built to common architecture style in the Southern region, which was the house type included 03 compartments and 02 lean-tos, housing types of 'Rội' house and 'Rường' house" [11].

Due to such reasons, it is necessary to research on topics of Environmental solutions in traditional housing construction in the Cuu Long River Delta.

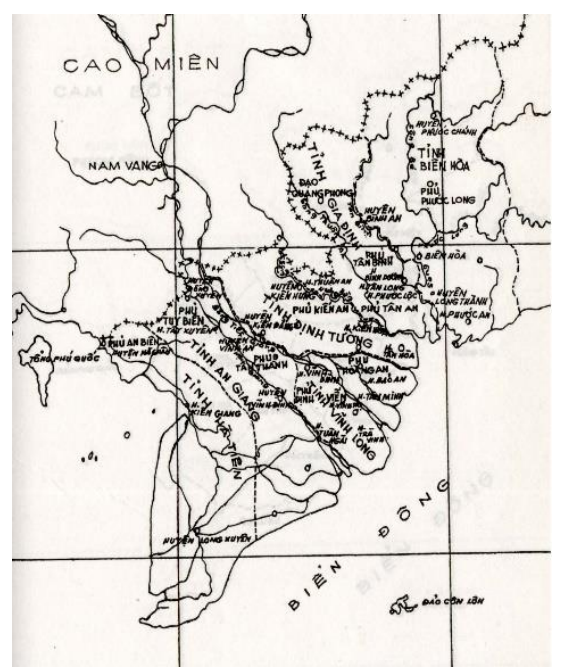

Fig. 1. The map of Cuu Long River Delta [Nguyen Dinh Dau].

\subsection{Research objectives}

With this research, the author expects to gain these results:

- To summarize lessons learnt from ancestors on Environmental solutions in traditional housing construction in the Cuu Long River Delta.

- To propose basic solutions on current Environmental solutions in traditional housing construction in the Cuu Long River Delta (weather change and sea level raise scenario not included).

\section{Objectives and research methods}

\subsection{Research objects}

\subsubsection{Natural environmental problems in the Cuu Long River Delta from the 17th to the mid 20th century}

The environment consists of two major areas: natural environment and social environment. Addressing behaviors to the environment (natural and social) will create cultural behavior of the people. In this study, the author deals only with the natural environment and solutions to the natural environment problems of traditional housing construction in the Cuu Long River 
Delta. The Cuu Long Delta climate is basically tropical and humid and affected by monsoon. As compared to other tropical regions, its climate has a lower temperature and higher humidity. It is possible to summarize the characteristics of the Cuu Long River Delta climate as follows:

With a relatively high temperature background and almost unchanged year-round, the annual average temperature is $26-27^{\circ} \mathrm{C}$. The difference between the hottest month and the coldest month is no more than $4-5^{\circ} \mathrm{C}$. Equatorial temperature fluctuations with two polarities correspond to the time that the sun passes through the zenith (near the solstice) and the two poles correspond to the lowest solar latitudes'.

Average annual solar radiation (including direct and ambient) is quite high at approximately $376 \mathrm{cal} / \mathrm{cm}^{2}$.

Every year can be distinguished with two seasons according to wet rain (relatively high rainfall: $1976 \mathrm{~mm} /$ year): dry season coincides with winter through spring; The rainy season coincides with the summer monsoon through autumn. Humidity in rainy season exceeds $85 \%$, dry season humidity drops to around $75 \%$.

The climate of the Cuu Long River Delta is less changed, especially in the heat regime [09], annual high temperatures create a hot season throughout the year.

No winter season, the lowest temperature is not less than $10^{\circ} \mathrm{C}$, the highest one does not exceed 40. The Cuu Long River Delta influenced by equatorial air originating from the South Pacific, which is a warm, humid weather that forms the southern monsoon prevailing in the middle and late summer, often accompanied by frequent weather disturbances. Accompanied by heavy, cloudy, moderate and heavy rain.

Due to linear stretched coast covering the Cuu Long River Delta, making it almost like a peninsula; therefore, the sea is highly regulated, reducing the maximum temperature of the area adjacent to the equator; forming a characteristic, warm, humid, cool year-round climate (Figure 1).

In terms of topography, the Cuu Long River Delta has few low mountains in the west such as Ba Den, That Son (over $600 \mathrm{~m}$ high), the rest are low plains, many rivers where previously (in 17th-18th centuries) is dense jungle. In addition, the Cuu Long River Delta is located at downstream of the Mekong River, where it spawns into the sea, although it has the advantage of silt and fresh water in the rainy season, but there are also many implications for the sunny season when intrusion Salinity became widespread through immense river mouths, as the downward pressure on water from the upstream was reduced. The lack of fresh water has become "One of the most pressing needs of people living in the Cuu Long River Delta, especially in coastal areas such as Go Cong prior to 1903, residents of Go Cong provincial town used potable water carried by boats from Chợ lớn. Along with the construction of the provincial capital to become a city, with the increasing number of residents, the demand for clean drinking water in Go Cong center is becoming more urgent" [10].

The Cuu Long River Delta, which was formed basicly during the neo-tectonic period, is a mix of three typical topographical forms of mountains, plains and coastal terrains. Since its generation, the Cuu Long River Delta has had a varied abundance of flora and fauna.

\subsubsection{Traditional housing in the Cuu Long River Delta}

Due to the trade demands appearing quite early in the Cuu Long River Delta, housing construction was also very urgent here. Maintaining the traditional in harmony to the nature of the ancient Vietnamese in building the traditional house of the Vietnamese people in the Cuu Long River Delta was resulted from the fact that people always considers the harmony with nature in the arrangement of the housing master plan, from the whole house to every individual items. 
The traditional house of Vietnam in general and in the Cuu Long River Delta in particular, is basically the same function; it is the place for worship of the ancestors and the supernatural beings of different religions; a place where family members live, relax, have fun, having meals together.
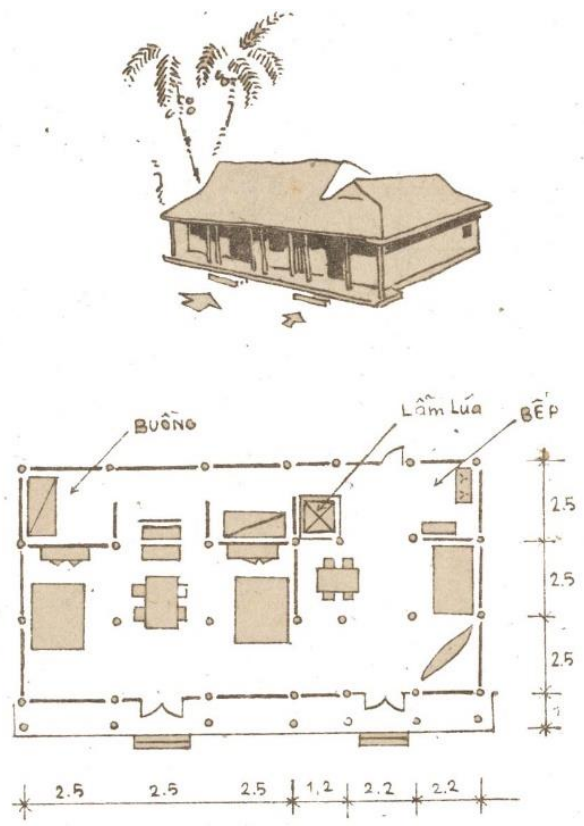

Fig. 2. The shape of the word 'Đinh' (Vo Dinh Diep).

However, in terms of functional space is somewhat different, the traditional house in the Cuu Long River Delta is usually in the shape of the word 'Đinh' (also known as 'T'), clearly divided into two compartments, four sides: Main, side, front, rear (Figure 2).

- In front of the main compartment (horizontal wing - also known as the upper house) is the most beautiful place, decorated with fine art and open space. This is a place of worship and receptions; The place for placing the altar and all kinds of tables, chairs, sofa, wooden bed ... for serving guests.

- Behind the main space is the place for bedroom, storage, enclosed space. In addition to the types of beds, boards, cabinets, shelves ... used for individual activities, this is also the place to place chests, boxes containing the property of the owner.

- In front of the side (the longitudinal side - also called the lower house) is the common place of the whole family and having meals.

- Behind the side are places for kitchen, storage room, women's reception area in the house, sometimes also a home production place of the family.

In the Cuu Long River Delta, traditional Vietnamese housing prior to the 19th century were made of wood (precious wood or mottled wood), with two basic forms: the 'Rội' house and the 'Rường' house. But whatever the housing forms, the number of house's compartment is usually odd $(1,3,5)$. 


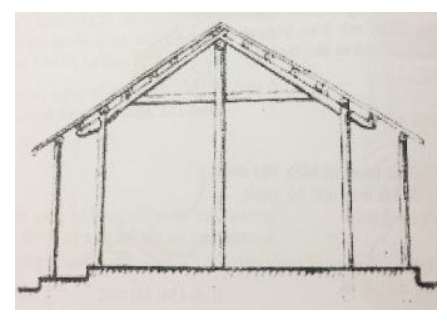

Fig. 3. 'Rội' house [16].

This is the most common form of home in the Cuu Long River Delta, poorly or moderately popular by the general public. The type of shelter is often made of logs such as: Calophyllum inophyllum (Mù-u), Spondias cythera (Cóc), Terminalia catappa (Bàng), Horsfieldia irya (săng máu), Samanea saman (Còng), Areca catechu (cau), Cocos nucifera (dừa), Bambusa sinospinosa (tre) ... are easy to find in the woods; Columns buried on the ground or on stone soles; Roof with leaves of nypa fruticans (lá xé), nypa plaited (lá chằm) or gutter tile (yin and yang); Astillen (vách) with Leaves of nipa, plaited nypa, wood of low quality, sometimes clay straw astillen. This type of building has the advantage of easy to build, easy to find materials, low cost, but the disadvantage is weak frame, short lifespan, small scale, vulnerable to termites. The house is usually temporary, dating from 3 to 5 years, less decorated aesthetic.

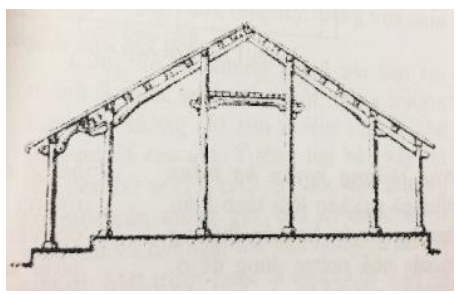

Fig. 4. 'Rường' house [16].

This form is usually found in prosperous areas such as townships or urban areas favored by wealthy people. The house is usually made of well-known woods such as: Copaifera officinalis (Gõ đỏ), Shorea obtusa (Cà chắc), Garcinia fag racoid es (Trai), Xylia xylocarpa (Căm-xe), Peltophorum pterocarpum (Lim), Tectona grandis (Giá tị) ... are usually purchased and transported from other places; Normal column on stone soles; House frame made of precious wood. Roof gutter tile, ceramic tile or 'French style' tile; Walls of precious wood or brick walls with 'Ô-dước' morta, firewood or cement-brick; Brick floor-tile (terracotta, 'Bát Tràng') or cement multicolour tile. This type of house has the advantage of stable frame, long life, durable, less termite. The house dates from at least 20 years to hundreds of years, decorated with a very sophisticated aesthetic. Disadvantages are complex construction, materials being bought and tranported from a long distance, construction costs are high. Mentioned above are two basic forms of traditional houses in the Cuu Long River Delta; besides, there are many variations and combinations of these two basic forms, such as: double 'rường' structure (bát dần) house, house of the hidden column, the octagonal (sóc đọi) form . Most of these types of variations often appear from the 19th century till now.

In general, whatever form of construction, traditional Cuu Long River Delta housing share some of the following features:

In terms of living environment, traditional Cuu Long River Delta housing are usually located in greenery, with rainwater ponds or lakes, with light fences surrounded with green trees. Generally, there is a front yard, rear yard or courtyard. The house is usually oriented in the direction of South, Southeast or direction to reach the river and canal. (Figure 5). 


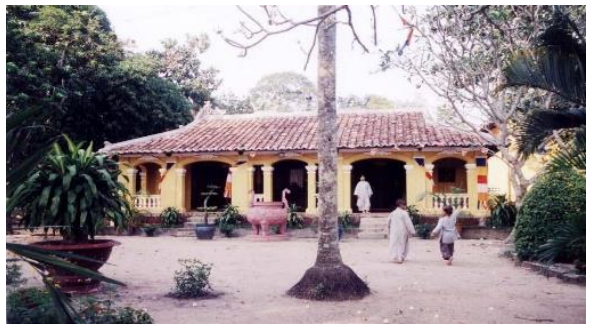

Fig. 5. House are usually located in a garden [2].

Considering housing architecture:

- Heat-resistant roof (large thermal resistance or air ventilation) provided and good drainage (thick foamed roof - Leaves of nipa, or multiple vented gutters - Vee gutter tile) (Figure 6), high slope and extruded canopy or wall,

- Thick or porous heat insulation walls (soil-made wall) or without wall for wind gone through. Sometimes the eclectic solution, such as thin walls (partition walls), with air vents; this type of wall absorbs heat quickly but also releases heat easily.

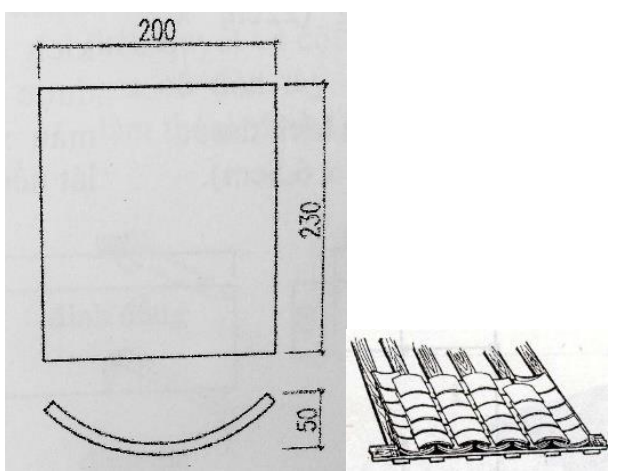

Fig. 6. Vee gutter tile [16].

- The raised foundation made of burned bricks or laterite, grounded with terracotta material (Chinese style tile) or clay, terracotta or laterite stone also comes from the 'soil' element, harmonized with surrounding environment (Figure 7). In places where the humidity is often low, the floor is made of wood material with pillars on the ground.

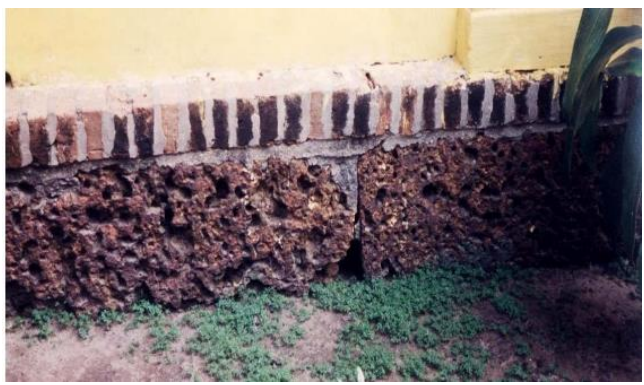

Fig. 7. Foundation made of over-burned bricks or laterites [2].

- House frame made of woods, the structure of the joints, bearing load force on columns on stone soles (Figure 8) to prevent damp (except the 'Rội' house which joined into the ground). Mortise structure is easy to disassemble when moving the house or assailling where regular tide happens. Houses does not raised to height. 


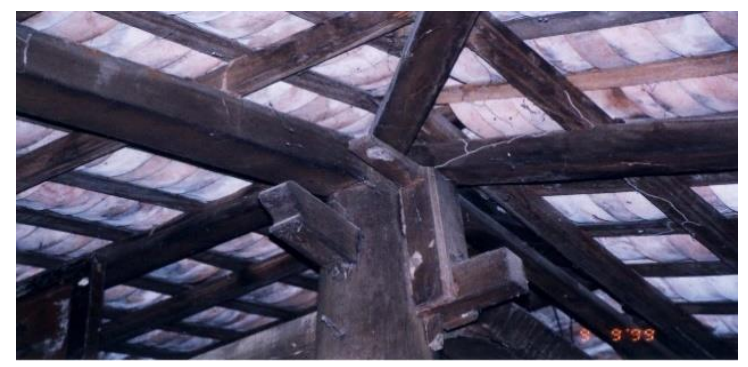

Fig. 8. Wooden frame, the structure of the joints [2].

- Flexible door, easy to be removed when required, or anti-push, upper and lower ventilation. Typically, the traditional upper and lower louvers door with panel in the middle.

- There is usually an eaves (or verandah) before or behind, or both as a transitional space in addition to the thermal radiation and rainfall combination .

- The triangular gable wall is usually airy to create air ventilation (from east to west) (Figure 9).

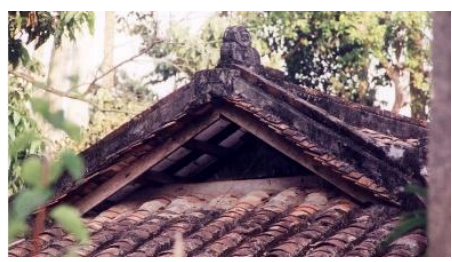

Fig. 9. Triangular gable [2].

- Doors (or windows) with direct access to outside, closed to eaves, often with an ornamental roof (door edge - auvant).

\subsection{Research methods}

Based upon fieldwork and statistics on environment data (Study Objective 1 in Subsection 2.1.1), the author analyzes and evaluates them in two aspects: Advantages and disadvantages for building traditional housing in the Cuu Long River Delta.

Upon historical method the author identifies environmental situations in the Cuu Long River Delta in the context of the specific history of the 18th - 19th centuries, the period in which the traditional housing is best shaped to examine.

By the inductive method, the author compares and contrasts with the construction of traditional houses there (Subjects 2 in subsection 2.1.2) in the same historical period for logic solutions to environmental problems done by ancestors in the construction of traditional houses in the Cuu Long River Delta. Thus, to conduct this study, the author has used the combination of four main methods: fieldword - statistics - logical history, inductive.

\subsubsection{Analyzing the status quo of the environment in the Cuu Long River Delta in the 18th century}

Based on research data statistics on the state of the natural environment in the Cuu Long River Delta (sub-section 2.1.1), it is possible to analyze and evaluate environmental issues here in the 18th century, to identify the environmental factors that directly affect the housing construction in the Cuu Long River Delta, as follows:

Advantages of the environment (Strength):

Due to its location being near the equator so there is no winter The Cuu Long River Delta. 
Long-stretched linear coast having effects of thermal regulating, reducing the maximum temperature of the equatorial vicinity so the wind is cool all year round.

Although there are certain influences by storms in the north and the central region, the Cuu Long River Delta seldom has annual storms.

The terrain is mostly flat, with dense network of rivers and canals.

Environmental problem (Weakness).

Hot and humid climate, hot sunshine, heavy rain, high humidity. There are two seasons: rainy and dry seasons, affected by the south monsoon.

There is a high temperature background that is almost stable all year-round, temperature changes in equatorial form, creating a sunny season that lasts throughout the year.

High humidity in the rainy season, coincides with the summer monsoon in the autumn through Thu (April to October) along with weather disturbance often accompanied by bad weather with heavy rain.

Usually flooded in the rainy season due to the floods from the upper Mekong, but lack of fresh water in the dry season. People often move to temporary areas which are more suitable for their life, adjacent to water bodies....

\section{Research result}

\subsection{Lessons on resonable responsiveness from ancestors for environmental solution in traditional housing construction in the cuu long river delta.}

Statistics on research objects towards situation of traditional housing in the Cuu Long River Delta (item 2.1.2) as compared to direct environmental factors shows how people at that time responsed to natural condition.

\subsubsection{Make use of advantages from natural conditions in housing construction in the Cuu Long River Delta}

Firstly, to make use of local weather without cold-release panel. It is not necessary to prevent cold wind nor air-conditioner. It is nearly no chimney seen in local houses, which can only be seen in big cities where adopt Western custom, but is considered as an imported taste only, not a local environmental measure.

Secondly, to make use of annual cool wind, prevailing sea wind from South and East direction, particularly wind from South-East, houses are commonly planned with main doors towards these directions to receive favor wind.

Due to rare storm condition, people did not care against stormy situation. That is why houses are built with high, simple, and thin structure, particularly less inclined brace-beam or door-stop can be seen compared to other regions.

Due to flat terrain condition and wood-mortise structure house, this makes the house quite stable. That is why house bearing load is focused on columns then put on stone, is considerably reasonable.

\subsubsection{Responsively natural environmental solution for difficulty in housing construction in the Cuu Long River Delta}

How to response upon environmental difficulties in housing construction in the Cuu Long River Delta is one of the local people's concerns, respected from their sophisticated solution. 
Due to hot and wet weather condition, considered as favorable for insect growth and unfavorable for human's livings. In order to cope with this weather disadvantages, people in the Cuu Long River Delta has experienced with certain solutions:

- Construction measures to minimize thermal radiation caused from excessive hot weather are expressed in certain structures:

- Very thick material and spongy thermal-resist layer for roofing such as coconut palm, thatch, small burn tiles with many tiny fissure for thermal and ventilation purposes (eaves gutter tiles). Then the 'Tây' tile were also used due to its similar heat-resist features.

○ In line with roofing measures, natural ventilation measures were also taken into consideration; particularly: at the two gable walls at two roof ends creates air flow in between to throw humid heat away of the roof, to reduce heat inside the house.

- Covering wall structure is also an considerably efficient anti-thermal measure. Like the roof, the wall structure thickness is considerable with high thermal resistance such as leaves of nypa fruticans (lá xé), soil with straw, 'Bổ kho' wall (made of woods, which overlapped edges to create chinks for heat release), particularly the "Chấn song" wall (Figure 10) favorable for air ventilation throughout the room then push heat radiation outside.

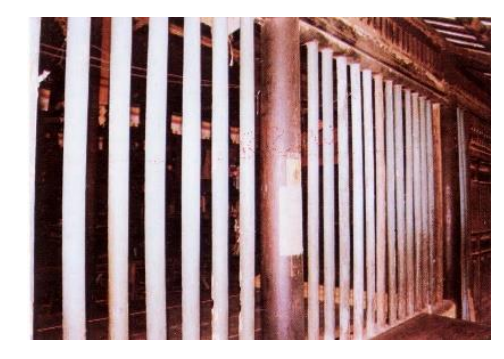

Fig.10. The 'chấn song' wall [2].

- Humidity prevention measure in housing construction:

- Sloping roof for quick rain water release, particularly eaves tile which is good for water release when roof slope is not favorable.

- Load-bearing house frame is often made of woods, put on stone soles on the ground (Figure 11).

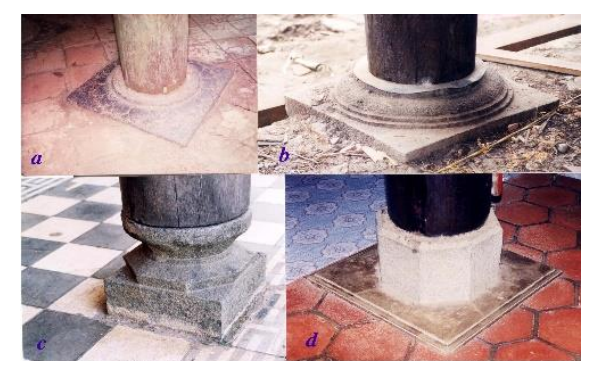

Fig. 11. Stone soles [2].

- House plan shows louver doors arranged to prevailing wind flow, usually with large corridor and cantilever roof, which is used both for living room transitional between inside and outside, also to prevent rain water splashing inside.

- Preventive measure for rain water splash through direct outside door and window without canopy, this is usually allocated at door edge (door canopy, cantilever).

- Floor made of compacted soil with crushed brick or burn soil tiling, raised foundation floor to prevent water partially flowing in. This is also measure to prevent material being elastic or shrinks caused from tropical weather varying. 
- Wood mortise structure (articulation brace) (Figure 12) allows certain varying resilience character of materials. This is considerably a measure to cope with hot-cool instantly varying weather at the Cuu Long River Delta.

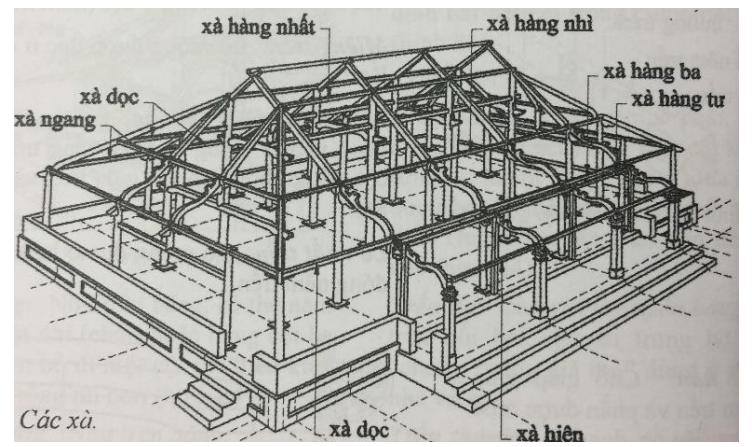

Fig. 12. Solution of the joint timber structure [16].

- To cope with yearly stable hot temperature with yearly long dry season, our ancestors have built their houses in an active way:

○ Long-term speaking, the whole house is usually linked to garden and fish pond (or sometimes with old big tree) for both cultivation and cool micro climate around the house.

- Dynamic measure in large openings allocation with easy operation make favorable air ventilation and heat release. This can be gained by using sliding louver, upper louverlower panel doors. Those are considered as typical examples.

- Ventilation measures for upper wall, which offers constant thermal air convection and being considered as basic solution.

- Construction measures for adaptation to high humidity in the rainy season, which can be seen under solutions used in housing in the Cuu Long River Delta:

o Retaining foundation wall with compacted ground soil which instantly contacted to outside humidity, where being frequent flooded in rainy season. Materials used in this case includes: laterite stone or over-burned brick, which comes from soil and proper to soil in terms of humidity prevention.

- Where constant humid and flooded ground in rainy season, the measure of raising the house on pillars with elevated floor -wood house on pillars is taken into consideration.

- Besides, natural ventilation for humid release is also used for houses in the Cuu Long River Delta.

- In case of partial flood in the rainy season caused from inundation from the upper Mekong, but in short of potable water in the dry season. People usually temporarily moves to other proper living areas. Measure to deal with these problems:

- Partial flood in rainy season can be solved with elevated houses on pillars, or elevated floor over the ground level.

○ Being short of potable water in dry season can be solved with ponds and water storage basin, building underground tanks or cisterns, burn-soil barrels or jars for annual water container use, particularly in coastal regions. That is why archaeology findings show many architecture typology of houses complex with water containers in the archaeological site of Óc-eo, which is adjacent to the Cuu Long River Delta.

- A common phenomenon in the Cuu Long River Delta could be seen in old times is that, the newcomers usually moved to new areas for earnings their livings, due to their economic shortcomings. This can be seen as a social phenomenon and a result from poverty (caused from feudal landlord period), and also from shortage of potable water environment. This is why dynamic solutions for housing materials are taken into consideration - wooden 
structure houses (common local materials at that time), with mortise linkage, easy for installation and removal, which was a normal choice in this period.

\subsection{Proposal of fundamental solution for current housing construction in the Cuu long river delta}

Though with advanced technology in this 21 st century, which being expected to solve any world-wide problems raised. Nevertheless, science advancement does not always satisfy people, particularly it is somehow strange and expensive. And even more serious, it could contradict the traditional culture. To this consideration, the way people behave to nature is the sustainable solution in housing construction. This is particular true for the Cuu Long River Delta. To this guideline and with consideration to current living condition of the people in the Cuu Long River Delta, which is weather change in line with other environmental conditions as temperature, humidity, drought, rain, typhoon, storm (item 2.1.1). These conditions seem remain unchanged or not much changed, compared to those in 18th century, except weather change. That is the reason why proposals on Environmental solutions in traditional housing construction in the Cuu Long River Delta are similar to the those in the 18 th century. Comparison upon natural condition, the author has summarized environmental solutions for housing construction as followed:

No winter cold wind shield and air-conditioning in architecture.

Prevailed wind housing should be from the South, particularly from the South-East.

Simple structure and modern materials should be used, restrain woods using (currently valuable); temporary houses could be built with bamboo, leaves, common woods.

Sloping roof for rain water drainage (flat roof not adapted to hot and humid weather), roofing material with high thermal resistance.

External, internal walls made of high thermal resistance material, upper-lower air ventilation for covering walls structure to let air flow inside and beneath the roof.

Transitional spaces inside and outside the house (corridor, balcony, openings, lobby, ..) for limiting rain throw and partial radiation.

It is necessary to have canopy, opening edge at (door, window) directly opened to outside.

Floor level should be high, floor tiling material should be suitable to the ground expansion.

Favorably, housing in the Cuu Long River Delta should be allocated in a fish-pond and garden space.

Ventilating openings (louvers, flaps, ..). Closed or panel openings are not recommended.

Solid and humid resistance materials recommended for floor consolidating and curbs.

House on stilt recommended for flooded areas.

As stated above (item 3.1.1), those mentioned are certain solution for natural environmental housing solutions in the Cuu Long River Delta.

\section{Discussion}

These results play an important role to current building trend, as well as an warning to designs far away from traditional value (which means cultural traditional in architecture and construction as stated by the author), those designs which follow forms that haven't been or not proper to people's living condition.

While we learn from advanced world-wide lessons, what we need to do, is to receive new technology with consideration to cultural tradition, which was generated from long history of adaptation to nature. Those were local weather condition in the Cuu Long River Delta. Differences in natural and local conditions need different culture and behavior; which 
resulted in different ways of housing construction, too. It is not advised to imitate the same blended (original imitation) solution learnt in other places without caution.

Those practical research results mentioned above from the author upon data site survey. What we recognize by comparison what ancestors did in old times and what people do nowadays? What is the level of appropriation to nature of new architecture-construction solutions? The four privileged fundamental elements in architecture-construction are: efficient, aesthetic, solid, economical; is there currently any upset to this priority? It is not easy to answer seriously and satisfactorily to these questions, while new renovation trends commonly exist in nowadays designers. These mentioned solutions can be considered as recommendations, though they are not really adequate; but they can be considered for an advanced (evidently) and traditional culture (Cuu Long River Delta people in this research).

The author agrees to statement of Nguyen Duc Thiem - professor in architecture - with his statement: "Housing is the family's sweet home, where it is firstly a residence against wild animals and harsh weather condition like drought, typhoon, storm" [14, page 212]; Nevertheless, the author limits the research scope within 02 research objects, which are the environment and traditional house, with more practically considered to the reality.

As presented at the beginning of item 3.1.1 in this research, what the author mentions "not really adequate", due to the fact that there is an important aspect which hasn't been considered - the social environment - which makes differences in behaviors between different people in a same natural environment. Though not only natural and social environments generate, but also perception culture and community culture [13, page 30]; but together with cultural behavior to natural environment and cultural behavior to social environment, which "creates two sub-set" - as stated by Prof. Tran Ngoc Them [13, page 29] of the cultural system, in relating to the way how resident communities behave to those two types of environments. Further research questions proposed by the author are: Solutions for social environment in current housing construction in the Cuu Long River Delta.

\section{Conclusions}

Housing is closely related to people's living environment. Due to environment-related solutions, people in the Cuu Long River Delta has being built their houses. Behavioral solutions are hidden in each house as living experiences, and further necessary design ideas are included. Being stated in this research are reasonable lessons learnt from the ancestors, particular natural environmental solutions in building traditional houses in the Cuu Long River Delta.

When environmental conditions hasn't been considerably changed, it is necessary to inherit experiences from natural environmental solutions in building traditional houses in the Cuu Long River Delta. Proposals from the author are also considered as fundamental base for new construction, relatively appropriate to natural condition in the Cuu Long River Delta.

It is evident that these proposals are not particularly new, but they can be recommended for constructors and designers to be taken into consideration in their practice.

\section{References}

1. F.D.K. Ching, Structural Physics, Space and Order (Thống Kê, 2003)

2. Pham Anh Dung, Nam Bo pagoda architecture (Xây Dựng, 2013)

3. J. Gehl, Life between buildings (Xây Dựng, 2009)

4. Nguyen Ngoc Gia, Architectural Climate (Xây Dựng, 2010) 
5. Nguyen Xuan Hoanh, Traditional folk house of Vietnamese people in Vinh Long, (Lao Động, 2011)

6. W.S.W. Lim, Urban Planning According to Asian Ethics (Xây Dựng, 2007)

7. T. M. Nguyen, Building Architecture (Xây Dựng, 2007)

8. G. N. Hoang, Feng Shui and the Environment (Hải Phòng, 2007)

9. D. N. Pham, Solutions to Climate Climate in Vietnam (KH\&KT, 2002)

10. Many Authors, The Old and the Present of Nam Bo (Thời Đại - the magazine Xưa \& Nay, 2014)

11. Dong Nai Department of Culture, Sports and Tourism, Dong Nai ancient house architecture (Đồng Nai, 2011)

12. Le Van Thang, Tourism and Environment Curriculum (Hanoi National University, 2008)

13. Tran Ngoc Thêm, Finding Vietnamese Cultural Identity, Ho Chi Minh City (2002)

14. D. T. Nguyen, The socio-cultural aspects of architecture (Xây Dựng, 2008)

15. D. T. Nguyen, Basic Architecture (Xây Dựng, 2008)

16. T. T. V. Nguyen, The term traditional architecture of Hue (Thuận Hóa, 2010) 